\title{
SIMULASI GATEWAY LOAD BALANCE PROTOCOL MENGGUNAKAN METODE WEIGHT
}

\author{
Djoko Suprijatmono ${ }^{1}$, Iwan Hernawan ${ }^{2}$, Septa Setiadi ${ }^{3}$ \\ Program Studi Teknik Elektro, Fakultas Teknologi Industri, Institut Sains dan Teknologi Nasional \\ email : djokojte@gmail.com ${ }^{1}$, iwanhernawan@istn.ac.id ${ }^{2}$, septasetiadi1909@gmail.com ${ }^{3}$
}

\begin{abstract}
To support qualified IT operations, recently many companies have hired more than 1 (one) communication link as a redundancy and to improve High Availability or the availability of their network systems. One method to improve high availability of multi router networks (links) is to use Gateway Load Balance Protocol (GLBP) which is a protocol that works on OSI layer 3. Where the GLBP function is to divide the traffic load and as a failover function when one router / link is damaged. Gateway Load Balancing Protocol (GLBP) itself is born from the concept of load balancing, a concept that is useful for dividing / balancing loads or loads on multiple links to the same remote network. That way the network link will not be disturbed if there is damage caused by one of the routers. This thesis describes the concept of GLBP by using the weight method where network simulation tools use GNS3 software. The results obtained from the simulation with GLBP weight method sharing the router data load is determined by the weight value given to each router. Where Comparison of Weight Values given to the Router will determine the number of data packets transmitted to the router.
\end{abstract}

Keywords: High Availability, GLBP, Weight, Load Balance, Failover

\section{PENDAHULUAN}

Sistem Information Technology (IT) saat ini memegang peranan penting dalam kehidupan kita sehari-hari, karena dengan sistem IT memudahkan proses komunikasi secara efektif dan efisien walaupun dipisahkan oleh jarak dan waktu. Tak terkecuali dalam dunia usaha (bisnis) yang mutlak membutuhkan sistem IT, karena dapat memperlancar jalannya operasional suatu perusahaan sehingga lebih efektif. Untuk mendukung operasional IT yang mumpuni, belakangan ini banyak perusahaan menyewa lebih dari 1 (satu) link komunikasi sebagai redudancy atau backup link untuk meningkatkan High Availability (ketersediaan) sistem jaringannya. Salah satu metode untuk meningkatkan high availability (ketersediaan) jaringan multi router (link) adalah menggunakan Gateway Load balance Protocol (GLBP) yang merupakan protocol yang bekerja pada layer 3 OSI (Open System Interconnection). Pada jurnal ini akan dibahas mengenai simulasi Gateway Load Balance Protocol (GLBP) menggunakan metode weight.

\section{TINJAUAN PUSTAKA}

Model Open System Interconnection (OSI) dan Arsitektur TCP/IP

Untuk mempermudah penggunaan, dan desain dari proses pengolahan data, serta untuk keseragaman pada vendor pembuat peralatan jaringan, International
Standard Organization (ISO) yang merupakan suatu konsorsium internasional, mengeluarkan suatu model lapisan jaringan yang disebut referensi model OSI. Didalam referansi model OSI, proses pengolahan data dibagi dalam tujuh lapisan / layer, yang masing masing lapisan memiliki fungsi tersendiri.

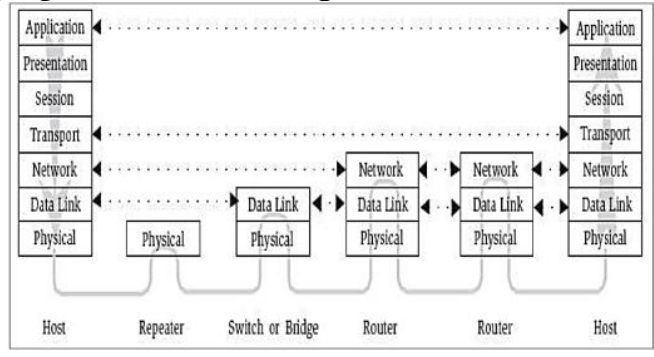

Gambar 2.1 Koneksi dalam Model OSI

\section{IP Address}

Internet protocol menggunakan IP address sebagai identitas. Pengiriman data akan dibungkus dalam paket dengan label berupa IP address si pengirim dan IP address penerima. Apabila IP penerima melihat pengiriman paket tersebut dengan identitas IP-address yang sesuai, maka datagram tersebut akan diambil dan disalurkan ke TCP melalui port, dimana aplikasi menunggunya. 
IP address terbagi dua (2) bagian, yaitu:

1. Network ID (Identitas Jaringan)

2. Host ID (Identitas Komputer)

\section{Routing}

Routing adalah proses pengiriman data maupun informasi dengan meneruskan paket data yang dikirim dari jaringan satu ke jaringan lainnya. Dalam jaringan WAN dikenal istilah TCP/IP (Transmission Control Protocol/ Internet Protocol) sebagai alamat sehingga pengiriman paket data dapat sampai ke alamat yang dituju (host tujuan). TCP/IP membagi tugas masingmasing mulai dari penerimaan paket data sampai pengiriman paket data dalam sistem sehingga jika terjadi permasalahan dalam pengiriman paket data dapat dipecahkan dengan baik. Berikut adalah jenis konfigurasi routing:

1. Static Routing, dibangun pada jaringan yang memiliki banyak gateway. jenis ini hanya memungkinkan untuk jaringan kecil dan stabil.

2. Dinamic Routing, biasanya digunakan pada jaringan yang memiliki lebih dari satu rute. Routing dinamis memerlukan routing protocol untuk membuat tabel routing yang dapat memakan resource komputer.

Untuk melakukan proses routing dibutuhkan router. Banyak vendor menyediakan router dengan kemampuan yang berbeda-beda tergantung spesifikasinya. Router yang banyak beredar di pasaran saat ini adalah Cisco yang akan dijelaskan pada point berikutnya.

\section{Router Cisco}

Router Cisco adalah suatu perangkat utama yang saat ini banyak digunakan pada jaringan area luas (WAN). Dengan router Cisco maka informasi dapat dilanjutkan dari satu komputer kepada komputer lainnya yang berada pada jaringan yang berlainan.

Karena Fungsi utama dari router adalah proses routing. Proses ini untuk meneruskan paket data dari suatu LAN menuju LAN lainnya yang saling berjauhan. Router menggunakan tabel informasi dan protokol routing yang berfungsi untuk mengatur lalu lintas data. Dengan adanya tabel informasi dan protokol routing tersebut maka paket data yang tiba akan diperiksa dahulu dan kemudian dilanjutkan kepada alamat yang dituju dengan cepat dan tepat.

\section{Switch}

Switch adalah perangkat jaringan komputer yang berfungsi sebagai konektor / penghubung. Dilihat dari fungsinya, terlihat mirip dengan Hub. Perbedaan kedua alat ini adalah soal besaran luas jaringan yang dapat dikerjakan dan besaran kecepatan transfer data. Switch memiliki cakupan luas jaringan yang lebih besar dari Hub, dan Switch juga memiliki kecepatan yang lebih tinggi dibanding dengan Hub. Sampai saat ini besaran kecepatan transfer data tertinggi Hub adalah 100 Mbps. Sementara Switch telah dikembangkan untuk dapat melakukan fungsinya dengan kecepatan diatas 100 Mbps. Bahkan ada yang hampir mendekati kecepatan $1 \mathrm{Gbps}$. Perbedaan Switch dan Hub juga terletak di tempat keduanya bekerja. Switch bekerja pada Layer 2 dan Layer 3. Sementara Hub bekerja pada Layer 1. Switch bekerja berdasarkan alamat MAC pada NIC (Network Interface Card). Hal ini bertujuan untuk mengetahui kemana paket data itu akan dikirim dan diterima. Sistem ini juga dibentuk agar tidak terjadi tabrakan pada jalur pengiriman data (collision) antara port satu dengan yang lain.

\section{Protocol GLBP (Gateway Load Balance Protocol)}

GLBP adalah sebuah protokol dengan fitur load balance (membagi beban sama rata) pada Router yang memungkinkan membuat Gateway atau pintu gerbang virtual menuju jaringan luar seperti metroethernet/internet/mpls yang terdiri dari dua jalur atau lebih. jadi dengan GLBP dapat membuat Gateway menuju internet yang sifatnya redundant atau memiliki link utama dan link cadangan sehingga ketika link utama terputus masih ada link cadangan sebagai backupnya. Protokol ini adalah Cisco Propriertary artinya hanya perangkat Cisco saja yang dapat menggunakan protokol ini. Untuk membuat Gateway yang redundant (memilik backup), GLBP harus tersetting pada beberapa router menjadi satu group GLBP. Setiap group terdiri dari dua atau lebih router sebagai gateway yang masing-masing router memiliki jalur menuju internet yang berbeda-beda atau bisa dibilang masing-masing Router Gateway terhubung dengan ISP yang berbeda-beda. Setiap satu group GLBP diidentifikasi dengan angka desimal 1 s/d 1023 dan diberikan alamat Virtual IP yang dapat digunakan sebagai Gateway menuju internet, tetapi setiap Router diberikan alamat Virtual MAC yang berbeda-beda, setiap Router juga menyimpan informasi alamat Virtual MAC Router temannya dalam satu group yang sama. 
Didalam satu group ada beberapa jenis Router berdasarkan tugasnya yaitu :

- AVG (Active Virtual Gateway), adalah Router yang bertindak sebagai ketua seluruh Router dari satu group GLBP, Router bertugas untuk menjawab pesan ARP dari PC yang isinya menanyakan alamat MAC dari Virtual IP satu group GLBP dimana Router AVG itu berada, isi jawaban Router AVG adalah alamat MAC-Virtual diri dia sendiri ataupun alamat MAC Virtual Router lainnya, seperti yang dijelaskan sebelumnya setiap Router menyimpan seluruh alamat MAC Virtual milik temannya dalam satu group, jadi Router AVG menjawab pesan ARP berdasarkan daftar alamat Virtual MAC yang dimiliki Router AVG. Router ini akan meneruskan sebuah lalu lintas menuju internet jika sebelumnya Router AVG ini menjawab pesan ARP dengan alamat Virtual MAC diri sendiri, sehingga ketika PC yang menerimanya pasti tujuan alamat MAC nya mengarah pada Router AVG ini.

- AVF (Active Virtual Forwarder), Router ini dapat sebagai wakil dari Router AVG, ketika Router AVG yang utama mati, maka Router AVF ini akan mendeteksinya dan menggantikan posisi Router AVG sebelumnya yang menjawab pesan ARP. Meskipun Router ini sebagai wakil tetapi router ini masih dapat meneruskan lalu lintas menuju internet. Router AVF akan meneruskan lalu lintas dari sebuah PC jika PC tersebut ketika mengirimkan pesan ARP menanyakan alamat MAC dari Virtual IP dan dijawab oleh Router AVG dengan alamat MAC Virtual Router AVF ini, pasti PC tersebut akan mengirim lalu lintas menuju alamat MAC Virtual dari Router AVF ini. Router AVF biasanya hanya terdapat 4 saja dalam satu group, jika lebih maka sisanya akan menjadi Router SVG.

- SVG (Standby Virtual Gateway), Router SVG juga sebagai wakil dari Router AVF ketika Router tersebut mati, Router ini juga masih dapat meneruskan lalu lintas menuju internet.

Load Balancing pada GLBP terdapat beberapa metode yaitu :

- Round-Robin, algoritma ini adalah default dari GLBP, jika pada satu group diatur dengan algoritma ini seperti yang dijelaskan sebelumnya, ketika ada salah satu PC yang pertama mengirimkan pesan ARP yang menanyakan alamat MAC Virtual dari Virtual IP, kemudian Router AVG akan menjawabnya dengan alamat MAC Virtual dari Router AVG itu sendiri (diri sendiri) sehingga PC yang pertama itu akan meneruskan lalu lintas menuju Router AVG itu. ketika ada PC lainnya yang kedua kalinya mengirimkan pesan ARP maka Router AVG akan menjawabnya dengan alamat MAC Virtual yang berbeda dengan sebelumnya yaitu alamat MAC Virtual Router AVF lainnya, sehingga PC yang kedua akan meneruskan lalu lintas menuju Router AVF yang jalurnya berbeda dengan PC pertama. Jadi dengan algoritma ini dalam satu group GLBP Router AVG akan menjawab pesan ARP dengan alamat MAC Virtual Router-Router secara berurutan, misalnya yang pertama dijawab dengan ...0101, yang kedua dijawab dengan 0102, dan yang ketiga adalah 0103, dst.

- Host Dependent, jika menggunakan algoritma ini sebuah PC akan menggunakan satu Router saja sebagai gateway nya secara tetap, misalnya PC kedua ketika meneruskan lalu lintas selalu pada Virtual MAC yang dimiliki oleh Router AVF ke 2.

- Weight, Pada algoritma ini, router yang memiliki nilai weight paling besar maka akan semakin banyak dan sering meneruskan lalu lintas ke arah WAN. Jika pada router tidak diberikan nilai weight, sesuai ketentuan Cisco maka router tersebut secara default akan memiliki nilai weight 100.

\section{GNS3}

GNS3 (Graphic Network Simulator) adalah software simulasi jaringan komputer berbasis GUI yang mirip dengan Cisco Packet Tracer. Namun pada GNS3 memungkinkan simulasi jaringan yang kompleks, karena menggunakan operating system asli dari perangkat jaringan seperti cisco dan juniper. Sehingga simulasi lebih nyata dalam mengkonfigurasi router langsung daripada di Cisco Packet Tracer. GNS3 adalah alat pelengkap yang sangat baik untuk laboratorium nyata bagi network engineer, administrator dan orang-orang yang ingin belajar untuk sertifikasi seperti Cisco CCNA, CCNP, CCIP dan CCIE serta Juniper JNCIA, JNCIS dan JNCIE. 


\section{STG (SNMP Traffic Grapher)}

STG merupakan software yang digunakan untuk monitoring trafik secara realtime. Secara default sample data yang diambil oleh STG adalah 1 detik, tetapi dapat diatur sesuai keinginan. Berikut gambar software STG.

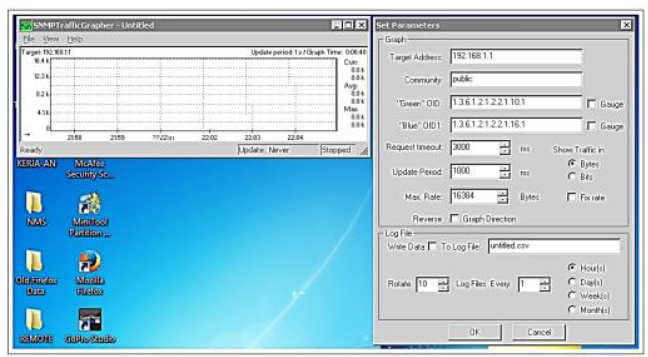

Gambar 2.2 Software STG

\section{TFGen (Traffic Generator)}

TFGen merupakan salah satu software yang berfungsi mengenerate traffic/beban untuk disalurkan pada sebuah jaringan. TFGen banyak digunakan untuk mengetest bandwidh suatu jaringan.

\begin{tabular}{|c|c|c|}
\hline \multicolumn{2}{|l|}{ IfGen } & $-|\square| x$ \\
\hline File Option Help & & \\
\hline Utilization[kbps] : & 4 & Start \\
\hline $\begin{array}{l}\text { Destination : } \\
\text { UDP Port: }\end{array}$ & $\begin{array}{r}\text { 127.0.0.1 } \\
\text { echo }\end{array}$ & Stop \\
\hline $\begin{array}{l}\text { Traffic Pattern } \\
\text { Period to update }\end{array}$ & Continuous and constant & \\
\hline
\end{tabular}

Gambar 2.3 Software TFGen

\section{SISTEM JARINGAN GATEWAY LOAD BALANCING PROTOCOL (GLBP)}

Untuk dapat mensimulasikan Gateway Load Balance Protocol, terlebih dahulu haruslah dibuat sistem jaringan komunikasi datanya. Minimal harus terdapat 2 link WAN yang dianalogikan terkoneksi ke provider atau 2 gateway beserta paramater-parameter pendukung lainnya agar protokol GLBP dapat berjalan dengan baik. Pada bab ini akan dibahas desain dan implementasi sistem jaringan komunikasi data yang mendukung penerapan Gateway Load Balance Protocol (GLBP)

\section{High Availability Network Services}

Ketersediaan (high availability) suatu jaringan menjadi hal utama yang perlu diperhatikan. Pada bagian ini akan dijelaskan desain yang mencakup jaringan high availability pada lapisan akses. Ketika merancang topologi jaringan untuk pelanggan yang memiliki sistem yang bersifat critical, sebelumnya harus ditentukan kemungkinan bahwa akan terjadi kegagalan pada komponen tertentu serta mendesain redudansi yang diperlukan untuk menangani masalah tersebut. Untuk menjalankan protocol GLBP, sebelumnya haruslah dibangun sebuah sistem komunikasi data yang memenuhi standard OSI Layer. Dimana di dalam sistem jaringan tersebut harus memenuhi minimal 4 layer. Yaitu layer 1 (Physical), layer 2 (Datalink), layer 3 (Network) dan layer 4 (Transport). Setelah sistem komunikasi data tersebut berjalan, maka protocol GLBP baru dapat disimulasikan.

\section{Topologi Sistem Jaringan Yang Mendukung GLBP}

Pada suatu sistem jaringan, Gateway Load Balancing Protocol adalah suatu teknik untuk mendistribusikan traffic atau paket data melalui dua atau lebih link komunikasi, dan umumnya sistem Load Balancing ini diterapkan pada perangkat Router yang langsung terhubung ke jaringan WAN. Di bawah ini adalah gambar analogi topologi sistem jaringan dengan Dual Link Wide Area Network (WAN) / multilink yang terkoneksi ke network provider dan menerapkan sistem Load Balancing dengan protocol GLBP (Gateway Load Balancing Protocol)

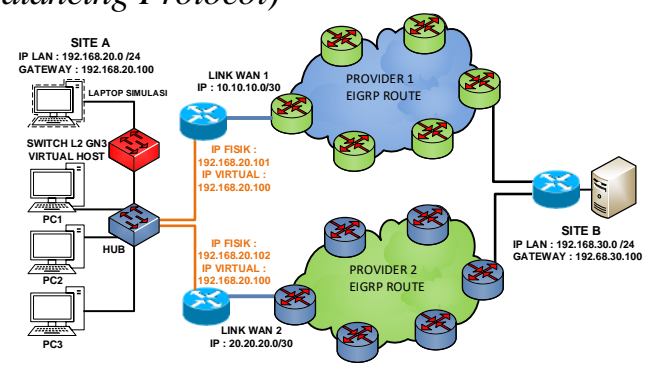

Gambar 2.4 Topologi Sistem Komunikasi Data

Pada Gambar 2.4, LAN pada dite A dengan Network ID 192.168.20.0/24 terhubung pada Switch layer 2 yang difungsikan sebagai HUB agar dapat terkoneksi ke jaringan WAN melalui router Link WAN 1 dan Router Link WAN 2 yang menerapkan konsep GLBP sebagai gateway redudancy dan load balancing traffic. Dimana tujuan koneksi LAN pada site A yaitu LAN site B dengan network ID 192.168.30.0 /24. Pada gambar topologi terdapat 5 parameter utama yang dapat memastikan topologi keseluruhan berjalan dengan baik. Adapun parameter yang dimaksud adalah sebagai berikut:

1. LAN Sistem jaringan

2. WAN Sistem Jaringan

3. Routing EIGRP Sistem jaringan

4. GLBP Metode Weight

5. IP Addressing dan Subnetting

\section{LAN (Local Area Network) Sistem Jaringan}

Sesuai gambar 2.4, terdapat 2 LAN dimana LAN 1 (site A) dengan network ID 192.168.20.0/24 dan LAN 2 (site B) dengan network ID 192.168.30.0 124. LAN 1 direpresentasikan sebagai source 
sedangkan LAN 2 direpresentasikan sebagai destination. Hardware pada LAN sesuai gambar 2.4 adalah sebagai berikut :

1. Switch L2 GNS3 Virtual Host

Switch ini merupakan fitur yang terdapat pada GNS3 dimana fungsinya agar laptop/PC penulis dapat terkoneksi pada desain network yang dibuat. Sehingga laptop penulis dapat terkoneksi ke semua perangkat yang ada pada topologi network sehingga dapat melakukan capture maupun generate traffic sebagai bagian dari simulasi.

2. Switch

Switch pada LAN site A difungsikan sebagai penghubung antara PC1, PC2 dan PC3 ke router yang nantinya akan diteruskan ke network provider agar dapat berkomunikasi dengan LAN di site B

3. Router

Router memiliki 2 fungsi yaitu sebagai penghubung LAN dan WAN (ke arah provider). Sehingga router merupakan bagian dari perangkat LAN dan merupakan gateway bagi PC1, PC2 dan PC3 di SITE A agar dapat terkoneksi ke LAN site B melalui network Provider 1 dan Network Provider 2.

\section{WAN (Wide Area Network) Sistem Jaringan}

Pada gambar 2.4, terdapat 2 WAN pada site A yang menjadi objek simulasi GLBP, dimana WAN 1 dengan network ID 10.10.10.0 /30 dan WAN 2 dengan network ID 20.20.20.0 /30. Masing-masing WAN terkoneksi ke network provider untuk seterusnya terkoneksi pada WAN di site B. Fungsi WAN adalah menghubungkan LAN di site A dengan LAN di site B yang umumnya jaraknya cukup jauh dan membutuhkan keterlibatan provider jaringan untuk merealisasikannya. Umumnya provider jaringan memanfaatkan teknologi media akses untuk menghubungkan 2 tempat yang jaraknya cukup jauh. Adapun media akses yang umum digunakan privider adalah sebagai berikut:

1. Teresterial
a. Fiber Optik
b. Kabel Tembaga
c. Radio Link
d. Broadband wireless akses

2. VSAT (Veri Small Aperture Terminal) / Satelit
Pada jurnal ini hanya dititik beratkan pada simulasi GLBP dimana bekerja pada segment LAN, sehingga untuk koneksi WAN hanya direpresentasikan dengan simulator GNS yang menghubungkan ethernet router di SITE A dengan router di sisi provider.

\section{Routing EIGRP Sistem Jaringan}

EIGRP adalah protokol routing yang termasuk proprietari Cisco, yang berarti hanya bisa dijalankan pada router Cisco, EIGRP bisa jadi merupakan protokol routing terbaik didunia jika bukan merupakan proprietari Cisco. Umumnya routing dinamic EIGRP digunakan sebagai metode failover ketika salah satu jalur mengalami kerusakan. Dalam jurnal ini fungsi failover tidak dijalankan oleh routing EIGRP tetapi oleh fungsi GLBP.

Kelebihan utama yang membedakan EIGRP dari protokol routing lainnya adalah EIGRP termasuk satu-satunya protokol routing yang menawarkan fitur backup route, dimana jika terjadi perubahan pada network, EIGRP tidak harus melakukan kalkulasi ulang untuk menentukan route terbaik karena bisa langsung menggunakan backup route. Kalkulasi ulang route terbaik dilakukan jika backup route juga mengalami kegagalan.

Karakteristik EIGRP:

1. Termasuk protokol routing distance vector tingkat lanjut (Advanced distance vector).

2. Waktu convergence yang cepat.

3. Mendukung multiple protokol network

4. Desain network yang flexible.

5. Manual summarization, EIGRP dapat melakukan summarization dimana saja.

6. Menjamin $100 \%$ topologi routing yang bebas looping.

7. Mudah dikonfigurasi untuk WAN dan LAN.

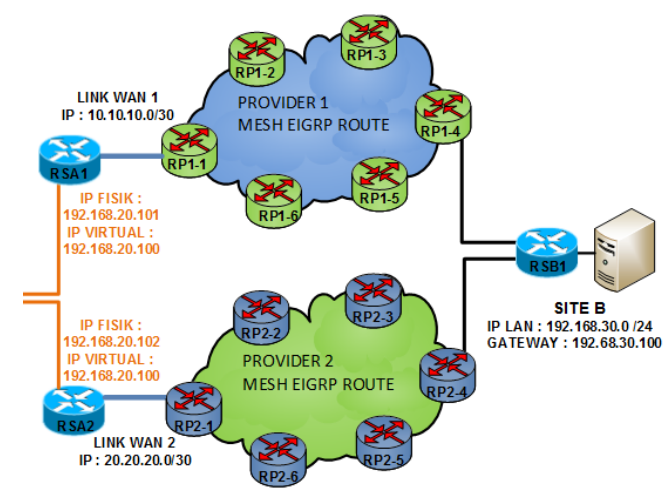

Gambar 2.5. Topologi Mesh Provider 
Routing EIGRP pada topologi simulasi di desain pada semua router baik di site A, Site B maupun pada router yang ada di provider 1 dan provider 2. EIGRP route site A terdapat pada 2 router yaitu RSA1 dan RSA2 yang terkoneksi pada router provder RP1-1 dan RP2-1. Sedangkan EIGRP pada site B router RSB1 terkoneksi ke 2 router provider yaitu RP1-4 dan RP2-4.

Routing EIGRP pada site A tidak didesain sebagai fungsi failover seperti layaknya dynamic route karena fungsi failover pada site A sudah diambil alih oleh GLBP yang terpasang pada interface LAN router RSA1 dan RSA2.

Routing EIGRP pada topologi simulasi sebagai fungsi failover berjalan pada router di network provider dan router pada site B. Dimana pada topologi mesh provider, EIGRP memegang peranan penting sebagai penjamin ketersediaan jaringan ketika penghubung antar router di network provider terjadi kegagalan koneksi dan mengharuskan EIGRP secara otomatis memilih jalur backup. Pun demikian pada site B, EIGRP menjamin ketersediaan jaringan ketika salah 1 lsatu koneksi ke provider mengalami kerusakan.

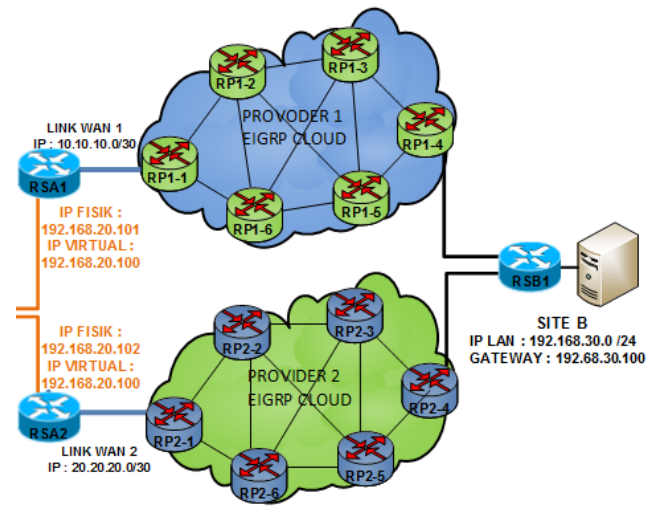

Gambar 2.6. Topologi Detil Mesh Provider

Pada gambar di atas terlihat pada network provider terdapat topologi mesh yang menghubungkan antar router. Dimana pada topologi tersebut menggunakan dymanic routing EIGRP dan dapat menjamin ketersediaan jaringan ketika salah satu link penghubung antar router mengalami kerusakan.

Sebagai ilustrasi, ketika gateway site A dengan IP 192.168.20.200 akan konek ke gateway site B dengan IP 192.168.30.100 akan tersedia 2 jalur koneksi WAN yaitu melalui WAN 1 dan WAN 2 .

Pemisalan PATH awal yang digunakan gateway Site A untuk konek ke gateway Site B adalah melalui $\mathrm{RSA} 1 \rightarrow \mathrm{RP} 1-1 \rightarrow \mathrm{RP} 1-2 \rightarrow \mathrm{RP} 1-3 \rightarrow \mathrm{RP} 1-4 \rightarrow$ RSB1, jika antara RP2 $\rightarrow$ RP3 mengali kerusakan koneksi, maka secara otomatis routing EIGRP akan menenjukan via jalur lain, misalkan RSA1 $\rightarrow$ RP1-1 $\rightarrow$ $\mathrm{RP1}-2 \rightarrow \mathrm{RP1}-5 \rightarrow \mathrm{RP1}-4 \rightarrow \mathrm{RSB} 1$ atau via jalur lain $\mathrm{RSA} 1 \rightarrow \mathrm{RP} 1-1 \rightarrow \mathrm{RP} 1-2 \rightarrow \mathrm{RP} 1-6 \rightarrow \mathrm{RP} 1-5 \rightarrow$
RP1-4 $\rightarrow$ RSB1. Pemilihan path redudancy EIGRP sendiri ditentukan oleh metode algoritma Distance Vector dimana memperhitungkan algoritma dari Hop Count, bandwidh dan delay dari masing-masing link penghubung antar router.

\section{GLBP Metode Weight}

GLBP melindungi traffik data dari kegagalan yang terjadi di router, seperti HSRP, GLBP memungkinkan paket berbagi beban pada sekelompok redundant routers. Setiap host dikonfigurasi menggunakan IP address virtual yang sama, dan semua router di dalam group router virtual ikut meneruskan paket. Anggota di dalam GLBP berkomunikasi menggunakan pesan Hello setiap tiga detik menggunakan multicast address 224.0.0.102, User Datagram Protocol (UDP) port 3222.

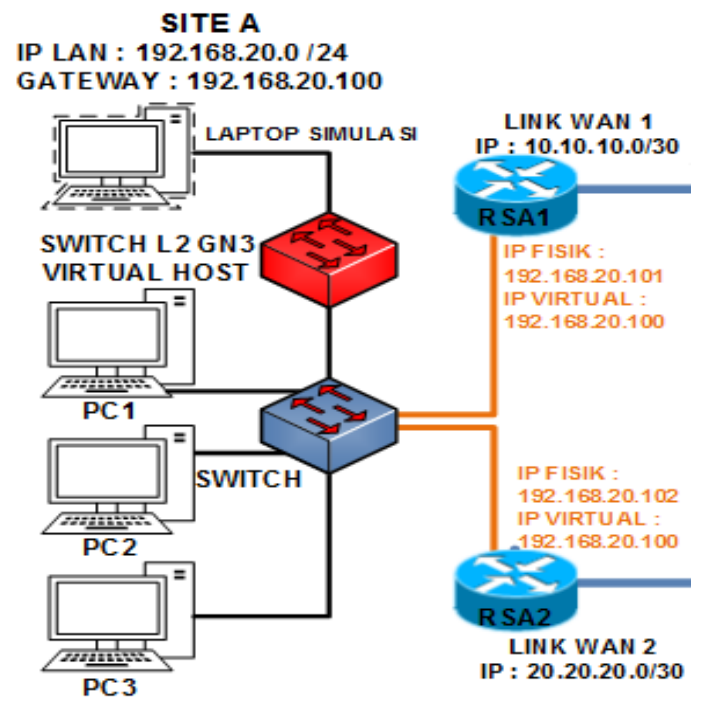

Gambar 2.7. GLBP Virtual Gateway berikut:

Keuntungan menggunakan GLBP sebagai

1. Load sharing: GLBP dapat dikonfigurasikan untuk jalan yang dipakai bersamaan untuk traffic client LAN menggunakan multiple routers.

2. Multiple virtual routers: GLBP mendukung hingga 1024 router virtual pada setiap interface fisik dari sebuah router.

3. Preemption: GLBP memungkinkan untuk menginterupsi gateway virtual yang aktif dengan backup yang mempunyai higherpriority.

4. Authentication: mendukung otentikasi simple text password. 
Pada gambar Gambar 2.7, semua PC pada site A terkoneksi ke switch yang kemudian diteruskan untuk terkoneksi ke 2 router yang terkoneksi pada router/jalur WAN yang berbeda via RSA1 dan RSA2. Sejatinya PC hanya bisa terkoneksi ke satu gateway saja untuk dapat berkomunikasi. Dengan metode GLBP, 2 gateway fisik yang ada pada interface ethernet LAN RSA1 dan RSA2 dikonversi menjadi satu gateway virtual dengan IP 192.168.20.100 yang dijadikan sebagai gateway PC.

Pada jurnal ini nilai weight yang digunakan adalah 100 pada router RSA2 yang merupkan nilai default (jika tidak dikonfigur) Cisco dan nilai 200 pada router RSA1 untuk memberikan perbandingan nilai 2:1 pada topologi yang bertujuan sebagai pembagi beban. Dimana sesuai aturan Cisco konstanta nilai weight yang dapat digunakan adalah 1 sampai 200. Pada simulasi ini nilai weight yang digunakan sebagai nilai perbandingan antara router RSA1 dan RSA2 yang nantinya akan menentukan jumlah packet data yang akan diteruskan sesuai nilai weight yang disetting. Sebagai ilustrasi metode weight, ketika nilai weight diberikan pada RSA1 adalah 200 dan pada RSA2 adalah 100, sesuai teori maka packet data yang dilewatkan pada router RSA1 akan lebih banyak 2 kali lipat daripada packet data yang dilewatkan pada router RSA2.

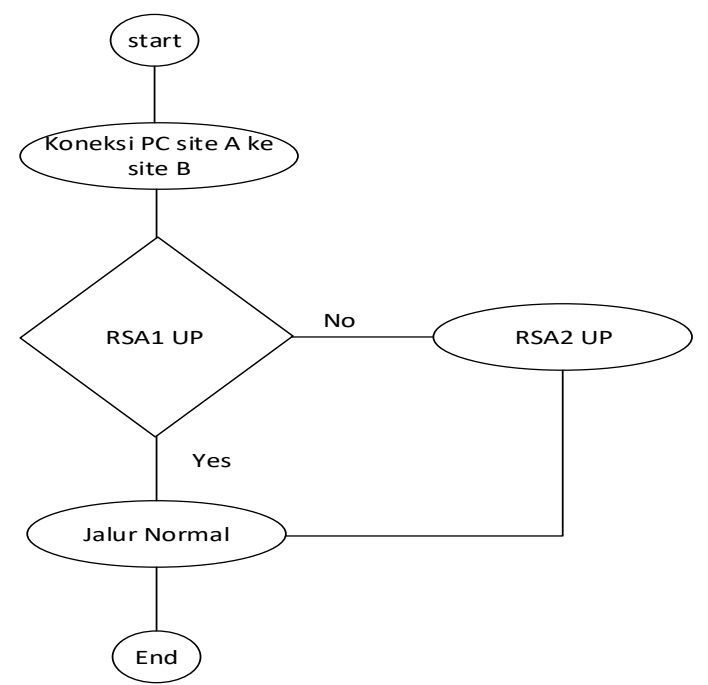

Gambar 2.8. Flow Chart Failover

Selain sebagai pembagi beban packet data, GLBP dengan metode weight juga berfungsi sebagai failover pada sistem jaringan. Sebagai ilustrasi dari gambar 3.1, path yang akan dilalui untuk menggambarkan situasi awal dari PC1 site A sampai PC di site B adalah sebagai berikut : $\mathrm{PC} 1 \rightarrow$ Switch $\rightarrow$ $\mathrm{RSA} 1 \rightarrow \mathrm{RP} 1-1 \rightarrow \mathrm{RP} 1-2 \rightarrow \mathrm{RP} 1-3 \rightarrow \mathrm{RP} 1-4 \rightarrow$ RSB1 $\rightarrow$ PC Site B. Jika terjadi kerusakan pada jalur koneksi WAN1 maka GLBP akan memindahkan jalur koneksi pada link WAN2 dengan detil sebagai berikut :
$\mathrm{PC} 1 \rightarrow$ Switch $\rightarrow$ RSA2 $\rightarrow$ RP2-1 $\rightarrow$ RP2-2 $\rightarrow$ RP2 $3 \rightarrow \mathrm{RP} 2-4 \rightarrow \mathrm{RSB} \rightarrow \mathrm{PC}$ site B.

\section{IP Addressing dan Subnetting Sistem Jaringan}

Alamat IP yang dimiliki oleh sebuah host dapat dibagi dengan menggunakan subnet mask jaringan ke dalam dua buah bagian, yakni:

1. Network Identifier / NetID atau Network Address (alamat jaringan) yang digunakan khusus menunjukkan identitas jaringan komputer tempat komputer dihubungkan.

2. Host Identifier / HostID atau Host address (alamat host) yang digunakan khusus untuk mengidentifikasikan alamat host di dalam jaringan.

Pada simulasi ini, IP addressing dibagi menjadi 3 bagian

1. IP LAN

IP LAN pada site A maupun site B digunakan IP Privat kelas $\mathrm{C}$ dimana pada site A diberikan network Id 192.168.20.0 /24 host Id 192.168.20.1 sampai dengan 192.168.20.254 dan Broadcast Id 192.168.20.255. Sedangkan Pada site B diberikan network Id 192.168.30.0, host Id 192.168.30.1 sampai dengan 192.168.30.254 dan Broadcast Id 192.168.30.255.

2. IP WAN Site

IP WAN pada site A maupun site B digunakan IP Privat kelas A dimana pada site A diberikan IP WAN link 1 dengan Network Id 10.10.10.0 /30, host Id 10.10.10.1 sampai dengan 10.10.10.2 dan Broadcast id 10.10.10.3, sedangkan IP WAN link 2 dengan Network Id 20.20.20.0 130, host Id 20.20.20.1 sampai dengan 20.20.20.2 dan Broadcast id 20.20.20.3. Pada site B diberikan IP WAN link 1 dengan Network Id 10.10.10.4/30, host Id 10.10.10.5 sampai dengan 10.10.10.6 dan Broadcast id 10.10.10.7, sedangkan IP WAN link 2 dengan Network Id 20.20.20.4 130, host Id 20.20.20.5 sampai dengan 20.20.20.6 dan Broadcast id 20.20.20.7.

3. IP WAN Provider

Pada provider 1 dan provider 2 hanya terdapat IP WAN karena IP yang ada merupakan penghubung antar router. Dimana diberikan IP Privat kelas B dengan subnetting 130 sehingga masing-masing koneksi antar router hanya memungkinkan 2 
ip host saja. Sebagai contoh penghubung router RP1-1 dan RP1-2 diberikan network Id 172.16.100.0 /30. Dimana pada router RP1-1 diberi IP 172.16.100.1/30 dan pada RP1-2 diberi IP 172.16.100.2/30 dengan Broadcast Id 172.16.100.3 /30

Penggunaan kelas IP address pada IP Privat dibebaskan selama mengikuti kaidah subnetting yang berfungsi untuk membatasi jumlah IP host yang terkoneksi dan berimplikasi pada kehandalan jaringan akibat kongesti jaringan serta meningkatkan faktor security jaringan.

\section{Konfigurasi Sistem}

Untuk melakukan konfigurasi sistem GLBP sesuai topologi dibutuhkan perangkat (Fitur Sofware simulator GNS3) dan software pendukung, yaitu:

1. Switch Cisco: 1 unit (GNS3)

2. Switch koneksi client internal: 1 unit (GNS3)

3. Router Cisco: 15 unit (GNS3)

4. Laptop: 1 unit

5. Software Traffic Generator (TFGEN)

6. Software SNMP Traffic Grapher (STG)

Semua perangkat dan software pendukung disimulasikan sesuai gambar 2.5. Fungsi masingmasingnya adalah:

1. Switch Cisco

Berfungsi untuk mendistribusikan gateway (Router) ke beberapa client (PC)

2. Router Cisco

Berfungsi untuk melakukan proses routing dan menjalankan protocol GLBP

3. Laptop

Berfungsi menjalankan keseluruhan projek, simulasi traffic (STG) dan pemberian beban (TFGen)

4. Software Traffic Generator (TFGEN)

Software untuk menghasilkan dan mengirimkan trafik dumy dari site A ke site B.

5. Software SNMP Traffic Grapher (STG)

Software untuk monitoring trafik pada kedua interface Router site A pada saat pengujian sistem.

Pada jurnal ini konfigurasi pada router provider tidak dibahas secara detil karena titik berat fokus permasalahan hanya pada sisi LAN dimana GLBP metode weight bekerja.

\section{List Tabel Interface dan IP Router Cisco Site A dan Site B}

Pada simulasi ini, data interface router Cisco ke arah jaringan WAN dan LAN dapat dilihat pada tabel 3.1 .

Tabel 2.1 Data Interface Pada Router

\begin{tabular}{|c|c|c|c|c|}
\hline No & Lokasi & Router & Interface & Fungsi \\
\hline \multirow{2}{*}{1} & \multirow{2}{*}{ SITE_A } & \multirow{2}{*}{ RSA1 } & Ethernet $0 / 1$ & Koneksi ke WAN \\
\cline { 4 - 5 } 2 & & Ethernet $0 / 0$ & Koneksi ke LAN \\
\hline \multirow{2}{*}{2} & \multirow{2}{*}{ SITE_A } & \multirow{2}{*}{ RSA2 } & Ethernet $0 / 1$ & Koneksi ke LAN \\
\cline { 4 - 5 } & & Ethernet $0 / 0$ & Koneksi ke WAN \\
\hline \multirow{2}{*}{3} & \multirow{2}{*}{ SITE_B } & \multirow{2}{*}{ RSB } & Ethernet 0/1 & Koneksi ke WAN \\
\cline { 4 - 5 } & & & Ethernet 0/0 & Koneksi ke LAN \\
\cline { 4 - 5 } & & & Ethernet $0 / 2$ & Koneksi ke WAN \\
\hline
\end{tabular}

Tabel 2.2 IP Address pada router Site A dan Site B

\begin{tabular}{|c|c|c|c|c|}
\hline No & Router & Interface & Ip Address & Subnet Mask \\
\hline 1 & RSA1 & Ethernet 0/0 & 192.168 .20 .101 & 255.255 .255 .0 \\
\hline 2 & RSA1 & Ethernet 0/1 & 10.10 .10 .1 & 255.255 .255 .252 \\
\hline 3 & RSA2 & Ethernet 0/0 & 20.20 .20 .1 & 255.255 .255 .252 \\
\hline 4 & RSA2 & Ethernet 0/1 & 192.168 .20 .102 & 255.255 .255 .0 \\
\hline 5 & RSB & Ethernet 0/0 & 192.168 .30 .101 & 255.255 .255 .0 \\
\hline 6 & RSB & Ethernet 0/1 & 10.10 .10 .6 & 255.255 .255 .252 \\
\hline 7 & RSB & Ethernet 0/2 & 20.20 .20 .6 & 255.255 .255 .252 \\
\hline
\end{tabular}

Tabel 2.2 merupakan list IP Address yang digunakan pada interface WAN dan interface LAN dari semua router sesuai desain topologi sistem jaringan Gateway Load Balance Protocol (GLBP)

\section{SIMULASI GATEWAY LOAD BALANCE PROTOCOL (GLBP) MENGGUNAKAN METODE WEIGHT}

Setelah sistem jaringan komunikasi data terkonfigur pada bab sebelumnya, pada bab ini akan dibahas mengenai pengujian sistem yang dimaksud. Selain itu pada bab ini akan disimulasikan serta dilakukan pengukuran simulasi gateway load balance protocol metode weight.

\section{Pengujian Sistem}

Setelah melakukan setting parameter seluruh perangkat seperti yang dijelaskan pada pembahasan diatas, langkah selanjutnya adalah menguji keseluruhan sistem tersebut sesuai topologi jaringan pada gambar 2.4. Berikut adalah langkah-langkah pengujian sistem:

1. Melakukan pengecekan status interface pada router

2. Melakukan pengecekan status interface pada switch

3. Melakukan pengecekan IP Adress pada router 
4. Melakukan Pengecekan ARP (Address Resolution Protocol) pada router

5. Melakukan pengecekan routing EIGRP

6. Melakukan pengecekan status GLBP

7. Melakukan pengecekan IP Adress pada PC

\section{Pengecekan Status Interface Pada Router}

Melakukan cek status interface router merupakan bagian dari standard OSI Layer 1. Dimana status interface ethernet pada router merepresentasikan kondisi Physical Layer (OSI) sudah terbentuk atau belum. Jika interface menunjukkan STATUS: UP PROTOCOL: UP, hal tersebut menunjukkan bahwa port interface router tersebut sudah terkoneksi dengan benar pada perangkat (router/switch) lawannya sehingga jalur physical dinyatakan Established.

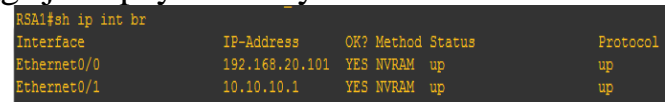

Gambar 2.9. Status Interface Router RSA1

Gambar 2.9. menunjukkan status interface arah LAN dan WAN pada router RSA1 di site A sudah UP dan berfungsi dengan baik. Hal ini ditunjukkan oleh layer 1 (status interface) UP dan layer 2 (status protocol) UP.

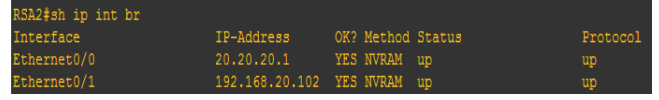

Gambar 2.10. Status Interface Router RSA2

Gambar 2.10 menunjukkan status interface arah LAN dan WAN pada router RSA2 di site A sudah UP dan berfungsi dengan baik. Hal ini ditunjukkan oleh layer 1 (status interface) UP dan layer 2 (status protocol) UP.

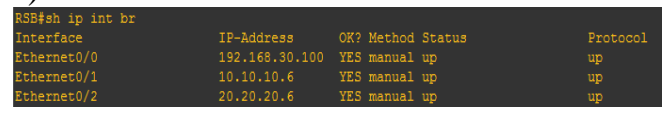

Gambar 2.11. Status Interface Router RSB

Gambar 2.11 menunjukkan status interface arah LAN dan WAN pada router RSB di site B sudah UP dan berfungsi dengan baik. Hal ini ditunjukkan oleh layer 1 (status interface) UP dan layer 2 (status protocol) UP.

\section{Pengecekan Status Interface Pada Switch}

Sama seperti pengecekan status interface pada router, Pengecekan status interface switch pun merupakan bagian dari standard OSI Layer 1. Dimana status interface ethernet pada switch merepresentasikan kondisi Physical Layer (OSI) sudah terbentuk atau belum. Jika interface menunjukkan STATUS: UP PROTOCOL: UP, hal tersebut menunjukkan bahwa port interface router tersebut sudah terkoneksi dengan benar pada perangkat (router/switch/PC) lawannya sehingga jalur physical dinyatakan Established.

$\begin{array}{lll}\text { 3W_lałsh int desc } & \\ \text { Interface } & \text { Status } & \text { Protocol Description } \\ \text { Eto/0 } & \text { up } & \text { up } \\ \text { Eto/1 } & \text { up } & \text { up } \\ \text { Eto/2 } & \text { up } & \text { up } \\ \text { Eto/3 } & \text { up } & \text { up } \\ \text { Et1/0 } & \text { up } & \text { up } \\ \text { Et } 1 / 1 & \text { up } & \text { up }\end{array}$

Gambar 2.11. Status Interface Switch

Pada gambar 2.11 menunjukkan switch sudah berfungsi dengan baik. Hal ini ditunjukkan dengan layer 1 (status interface) dan layer 2 (protocol) sudah UP.

$\begin{array}{lll}\text { sw_2 2\#sh int desc } & & \\ \text { Interface } & \text { Status } & \text { Protocol Description } \\ \text { Et } 0 / 0 & \text { up } & \text { up } \\ \text { Et } 0 / 1 & \text { up } & \text { up } \\ \text { Et } 0 / 2 & \text { up } & \text { up } \\ \text { Et } 0 / 3 & \text { up } & \text { up } \\ \text { Et } 1 / 0 & \text { up } & \text { up }\end{array}$

Gambar 2.12. Status Interface Switch Host Virtual

Pada gambar 2.12 menunjukkan switch Host Virtual sudah berfungsi dengan baik. Hal ini ditunjukkan dengan layer 1 (status interface) dan layer 2 (protocol) sudah UP.

\section{Pengecekan IP Adress Pada Router}

Sesuai Tabel 2.2: IP Address pada router, maka perlu dipastikan IP address pada semua router sudah terpasang dengan benar. Untuk melakukan pengecekan tersebut berikut langkah-langkahnya:

1. Sh ip int br: command ini ditujukan untuk melihat IP address yang terpasang pada interface router.

2. Command 'sh ip int br" selain untuk melihat status IP, juga dapat menunjukkan status interface dan protocol dari setiap interface yang terinstall pada router

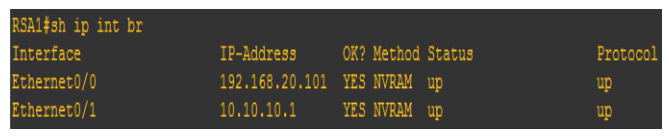

Gambar 2.12. Status IP Address pada router RSA1

Pada gambar 2.12 menunjukkan layer 3 (network) pada router RSA1 sudah berfungsi dengan baik. Hal tersebut ditunjukkan dengan status IP address yang terpasang sudah benar (sesuai dengan tabel 3.2) yaitu IP Address 10.10.10.1 untuk koneksi ke arah WAN dan 192.168.20.101 untuk IP Address ke arah LAN. 


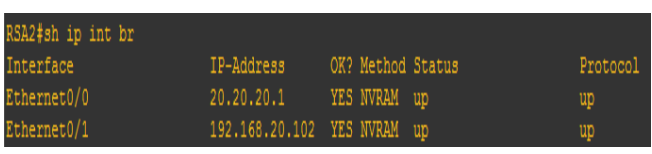

Gambar 2.13 Status IP Address pada router RSA2

Pada gambar 2.13 menunjukkan layer 3 (network) pada router RSA2 sudah berfungsi dengan baik. Hal tersebut ditunjukkan dengan status IP address yang terpasang sudah benar (sesuai dengan tabel 3.2) yaitu IP Address 20.20.20.1 untuk koneksi ke arah WAN dan 192.168.20.102 untuk IP Address ke arah LAN.

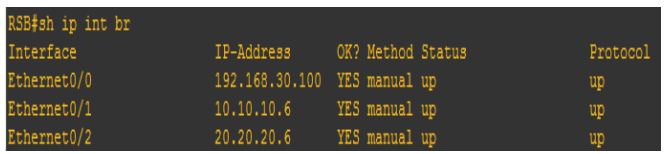

Gambar 2.14 Status IP Address pada router RSB

Pada gambar 2.14 menunjukkan layer 3 (network) pada router RSB sudah berfungsi dengan baik. Hal tersebut ditunjukkan dengan status IP address yang terpasang sudah benar (sesuai dengan tabel 3.2) yaitu IP Address 10.10.10.2 untuk koneksi ke arah WAN dan 192.168.30.101 untuk IP Address ke arah LAN.

\section{Pengecekan ARP (Address Resolution Protocol) Pada Router}

Address Resolutiom Protocol adalah salah satu protocol dalam OSI Layer yang ditujukan untuk melakukan pengecekan semua Mac-add yang terkorelasi dengan IP Address yang terkoneksi ke router. Protocol ini dapat digunakan untuk mendeteksi bahwa layer 2 (Mac-address) dan layer 3 (IP Adress) sudah terbentuk dengan benar.

\begin{tabular}{|c|c|c|c|c|c|}
\hline \multicolumn{6}{|c|}{ RSA1 $¥$ sh arp } \\
\hline Protocol & Address & Age (min) & Hardware Addr & Type & Interface \\
\hline sernet & 10.10 .10 .1 & - & $a a b b . c c 00.0310$ & ARPA & Ethernet $0 / 1$ \\
\hline ternet & 10.10 .10 .2 & 1 & aabb.cc00.0110 & ARPA & Ethernet $0 / 1$ \\
\hline ternet & 192.168 .20 .100 & - & $0007 . \mathrm{b} 400,0 \mathrm{a} 01$ & ARPA & Etherneto/0 \\
\hline rnet & 192.168 .20 .101 & - & aabb.cc00.0300 & ARPA & \\
\hline ternet & 192.1 & 0 & aabb. & ARPA & Ethernet $0 / 0$ \\
\hline Eernet & 192.168 .20 .200 & 0 & 0050.7966 .6800 & ARPA & Ethernet $0 / 0$ \\
\hline sernet & 192.16 & 0 & 0050.7966 .6801 & ARPA & Ethernet $0 / 0$ \\
\hline cernet & 192.168 .20 .202 & 0 & 0050.7966 .6802 & ARPA & Ethernet $0 / 0$ \\
\hline
\end{tabular}

Gambar 2.15 Status ARP \& IP Address pada router RSA1

Pada gambar 2.15 menunjukkan router RSA1 sudah dapat berkomunikasi dengan semua perangkat yang terhubung. Hal ini ditunjukkan munculnya semua IP address yang terkoneksi langsung dengan routerla.

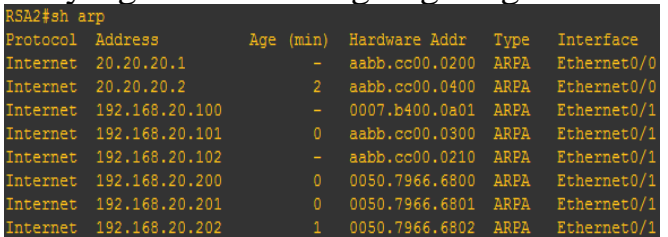

Gambar 2.16 Status ARP \& IP Address pada router RSA2
Pada gambar 2.16 menunjukkan router RSA2 sudah dapat berkomunikasi dengan semua perangkat yang terhubung. Hal ini ditunjukkan munculnya semua IP address yang terkoneksi langsung dengan router1b.

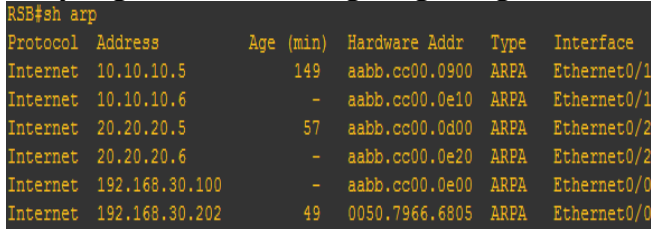

Gambar 2.17 Status ARP \& IP Address pada router $\mathrm{RSB}$

Pada gambar 2.17 menunjukkan router RSB sudah dapat berkomunikasi dengan semua perangkat yang terhubung. Hal ini ditunjukkan munculnya semua IP address yang terkoneksi langsung dengan router RSB.

\section{Pengecekan Routing EIGRP}

Setelah layer 1 dan 2 dipastikan established seperti dijelaskan pada point sebelumnya, langkah selanjutnya yaitu memastikan status routing EIGRP pada router sudah terpasang dan berjalan dengan baik.EIGRP sudah berjalan dengan baik ditunjukkan dengan status Uptime dan status routing table EIGRP seperti pada capture berikut :

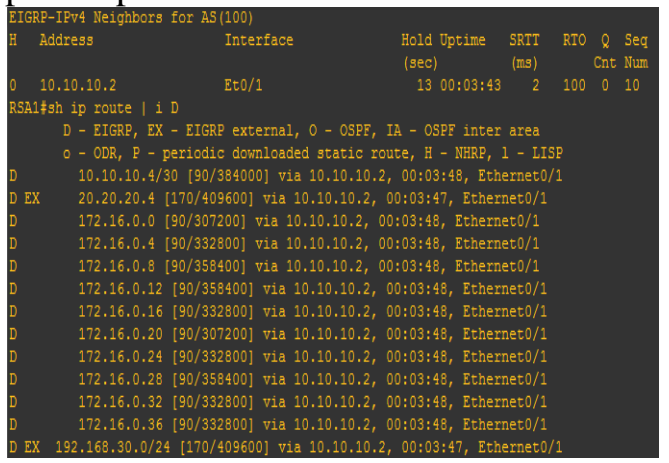

Gambar 2.18 Status EIGRP Dan Routing Table

\section{Router RSA1}

Pada gambar 2.18 status EIGRP router RSA sudah UP, ditujukkan hasil dari command "sh ip eigrp neighbors" yang memperlihatkan Uptime 00:03:43. Dan routing table eigrp sudah terbaca oleh routerla dimana ditunjukkan oleh status D EX dari command "sh ip route". 


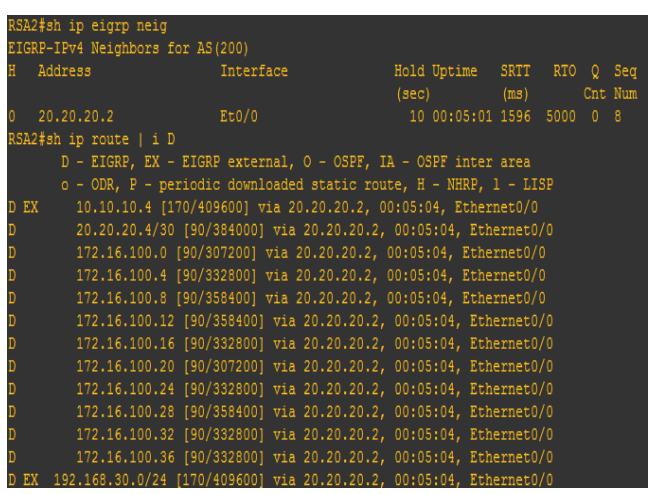

Gambar 2.19 Status EIGRP Dan Routing Table

\section{Router RSA2}

Pada gambar 2.19 status EIGRP router RSA2 sudah UP, ditujukkan hasil dari command "sh ip eigrp neighbors" yang memperlihatkan Uptime 00:05:01. Dan routing table eigrp sudah terbaca oleh routerla dimana ditunjukkan oleh status D EX dari command "sh ip route".

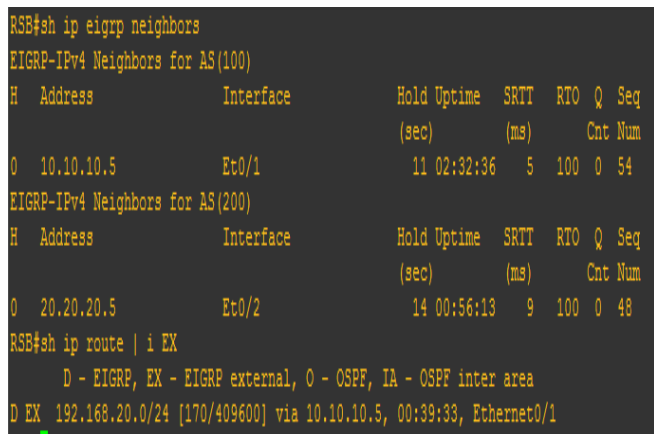
Router RSB

Gambar 2.20 Status EIGRP Dan Routing Table

Pada gambar 2.20 status EIGRP router2a sudah UP, ditujukkan hasil dari command "sh ip eigrp neighbors" yang memperlihatkan Uptime 02:42. Dan routing table eigrp sudah terbaca oleh router RSB dimana ditunjukkan oleh status D EX dari command "sh ip route".

\section{Pengecekan Status GLBP}

Pada seluruh router sebelumnya sudah disetting parameter GLBP pada interface ethernet LAN. Untuk itu berikut perlu dipastikan status GLBP sudah aktiv dan dapat bekerja dengan baik

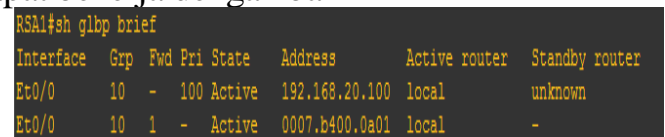

Gambar 2.21 Status GLBP router RSA1

Pada gambar 2.21 menunjukkan status GLBP router RSA1 sudah aktif. Hal tersebut ditunjukkan dengan status active baik IP address maupun macaddress virtual sebagai hasil dari command "sh glbp brief".

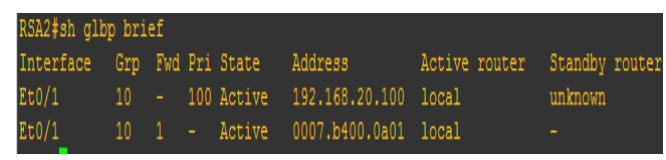

Gambar 2.22 Status GLBP router RSA2

Pada gambar 2.22 menunjukkan status GLBP router RSA2 sudah aktif. Hal tersebut ditunjukkan dengan status active baik IP address maupun macaddress virtual sebagai hasil dari command "sh glbp brief".

\section{Pengecekan IP Address pada PC}

Langkah terakhir untuk mendukung simulasi GLBP pada jaringan adalah dengan melakukan pengecekan IP Address pada PC yang ada dalam topologi. Setiap PC yang ada harus terkoneksi ke gateway sesuai topologinya, dimana site A (PC1, PC2, PC3) harus konek ke GLBP gateway 192.168.20.100. Dan site B (PC6) harus konek ke GLBP gateway 192.168.30.100.

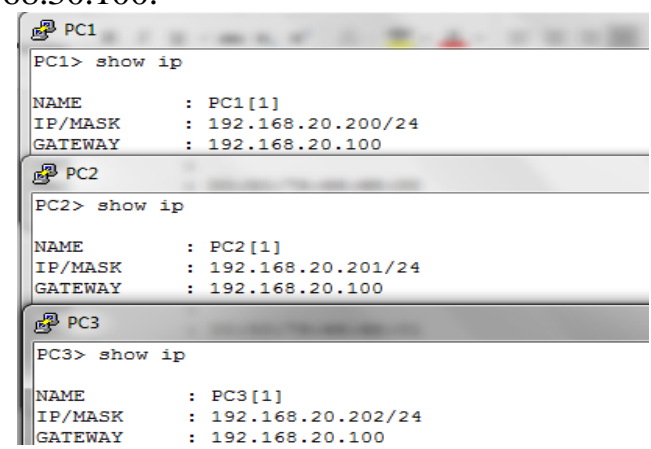

Gambar 2.23 Status IP Address PC di site A

Pada gambar 2.23 menunjukkan status IP address semua PC di site A (PC1, PC2 dan PC3) sudah aktif dan terkoneksi ke gateway 192.168.20.100.

$$
\begin{array}{ll}
- \text { PC1 } & =192.168 .20 .200 / 24 \\
- \text { PC2 } & =192.168 .20 .201 / 24 \\
- \text { PC3 } & =192.168 .20 .201 / 24
\end{array}
$$

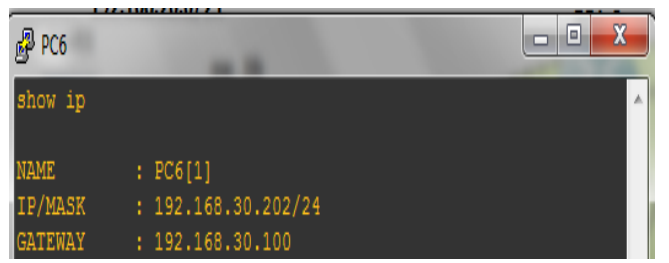

Gambar 2.24 Status IP Address PC di site B

Pada gambar 2.24 menunjukkan status IP address semua PC di site B (PC6) sudah aktif dan terkoneksi ke gateway 192.168.30.100.

- PC6 = 192.168.30.202/24 


\section{Pengujian Gateway Load Balancing Protocol}

Setelah semua parameter sistem dipastikan berjalan dengan baik. Langkah selanjutnya yaitu melakukan pengujian Gateway Load Balancing Protocol bekerja dengan baik. Adapun berikut langkah-langkahnya:

1. Show weight GLBP di router SITE A

2. Ping test dari PC SITE A ke PC SITE B

3. Traceroute dari PC SITE A ke SITE B

4. Test failover

5. Test failover GLBP metode weight dengan STG dan Traffic Generator

\section{Show Weight GLBP Di Router SITE A}

GLBP dengan metode weight menjadikan router dengan setting weight yang lebih besar akan lebih banyak dipilih untuk meneruskan paket data. Pada simulasi ini seluruh router disetting dengan weight 200, sehingga dengan weight yang sama secara teori meneruskan paket akan mirip dengan metode round robin.

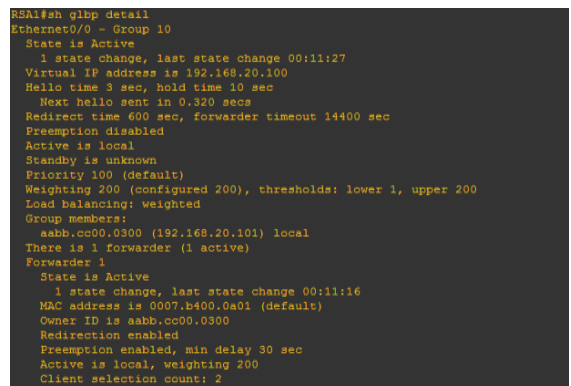

Gambar 2.25 Weight GLBP Pada Router RSA1

Pada gambar 2.25 router RSA1 menunjukkan weight terkonfigur 200 pada interface LAN.

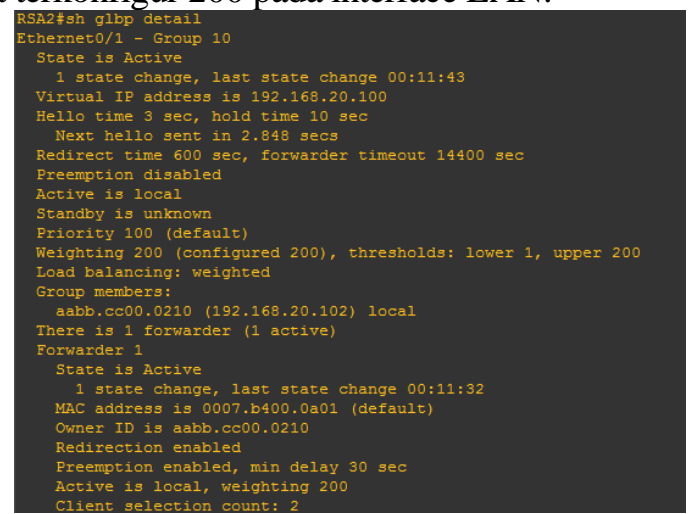

Gambar 2.25 Weight GLBP pada router RSA2

Pada gambar 2.25 router RSA2 menunjukkan weight terkonfigur 200 pada interface LAN.

\section{Ping Test Dari PC SITE A Ke PC SITE B}

Untuk memastikan simulasi berjalan dengan baik, dilakukan tes untuk memastikan PC dari site A sudah dapat berkomunikasi dengan PC di site B. Salah satu langkah untuk memastikan menggunakan command ping <IP tujuan>.

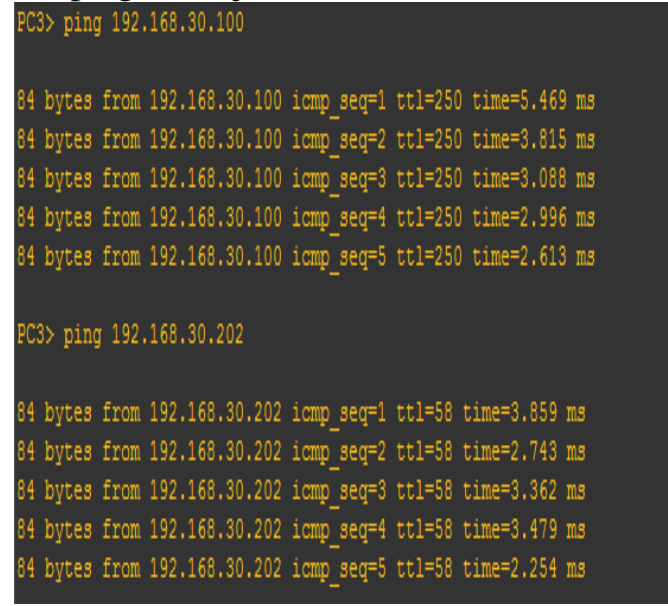

Gambar 2.26 Ping dari PC site A ke Gateway dan PC site $\mathrm{B}$

Pada gambar 2.26 menunjukkan bahwa PC3 di site A sudah dapat berkomunikasi dengan $\mathrm{PC}$ si dite $\mathrm{B}$ (PC6). Hal ini ditunjukkan dengan reply dari PC di site B saat dilakukan ping dari PC3 site A.

\section{Traceroute test dari PC SITE A ke PC SITE B}

Traceroute Weight Link 1 dan Link 2 sama besar $($ Weight $=200)$. Untuk memastikan GLBP berjalan dengan baik, salah satu cara identifikasinya menggunakan traceroute. Dikarenakan weight gateway GLBP di Router1a dan Router1b memiliki weight sama (200), maka paket data akan diforward secara bergantian melewati link1 dan link2.

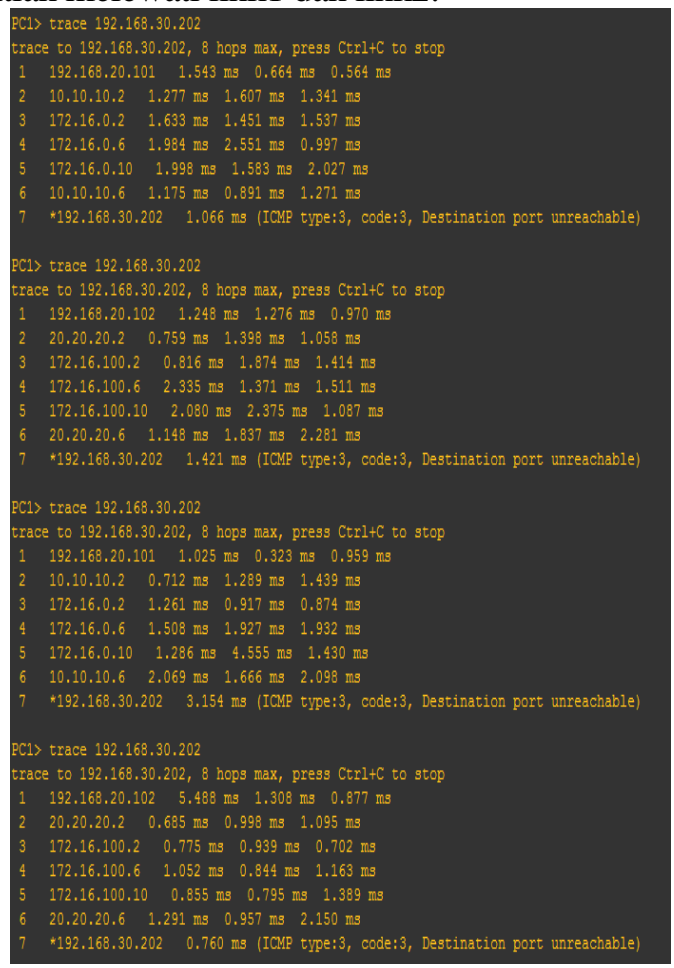

Gambar 2.27 Trace dari PC1 (SITE A) ke PC6 (SITE B) 
Pada gambar 2.27 menunjukkan traceroute dari site A (PC1) ke site B (PC6) dengan hasil path yang bergantian. Path ditunjukkan oleh IP WAN link, dimana IP WAN link 1 10.10.10.2 dan IP WAN link 2 20.20.20.2. Hal ini menunjukkan Weight sama (200) pada router sudah berjalan dengan baik dimana traffic terbagi bergantian pada kedua link WAN.

\section{Traceroute Weight Link $1>$ Weight Link 2}

Simulasi menggunakan weight yg berbeda antara link1 dan link 2, dimana setting link 1 weight 200 dan link 2 weight 100.

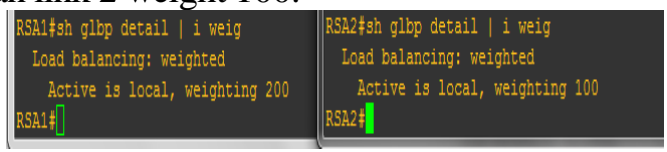

Gambar 2.28 Weight Link 1200 dan Weight Link 2100

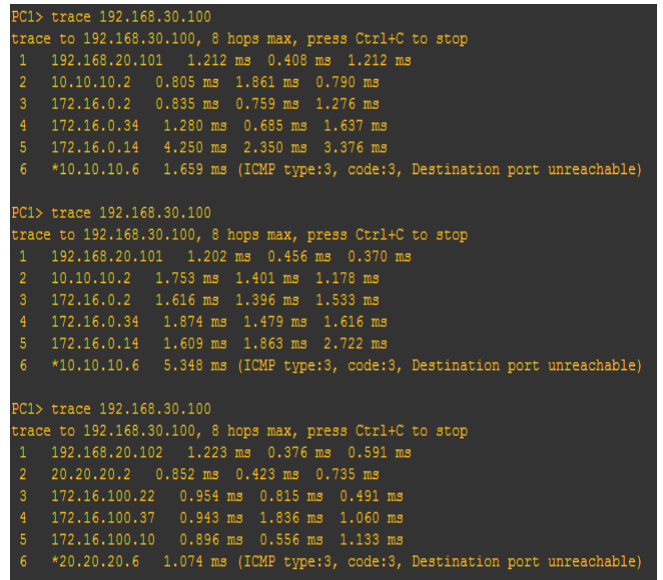

Gambar 2.28 Hasil Traceroute Link 1200 dan Weight Link 2100

Gambar 2.28 menunjukkan paket diteruskan pada link 1 sebanyak 2 kali dan ke link 2 sebanyak 1 kali. Hal ini menunjukkan bahwa pada GLBP metode weight, link dengan weight lebih besar akan meneruskan lebih banyak paket data.

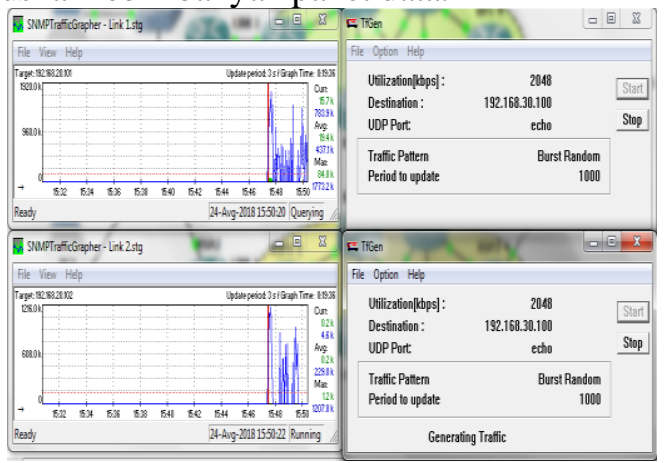

Gambar 2.29 Capture STG Weight Link 1200 dan Weight Link 2100
Pada gambar 2.29 terlihat AVG (Average) traffic yang melewati linkWAN 1 lebih besar daripada link WAN 2. Dimana average traffic yang link 1 sebesar 437,1 Kb dan link 2 sebesar 229,0 Kb.

\section{Test Failover GLBP Metode Weight}

Untuk memastikan sistem failover sistem jaringan GLBP metode weight ini, maka perlu membuat down salah 1 link (Link1) dengan cara menshutdown interface ETH0/0 di router RSA1. Pada simulasi failover ini weight kedua link tersetting 200.

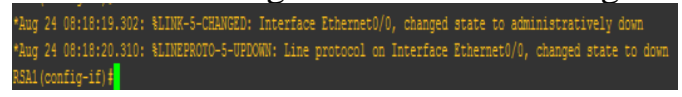

Gambar 2.30 Status Interface WAN link1 Down

Dengan putusnya salah 1 jalur komunikasi (link WAN1) maka ketersediaan link hanya bisa melewati link WAN 2 (IP WAN 20.20.20.0/30).

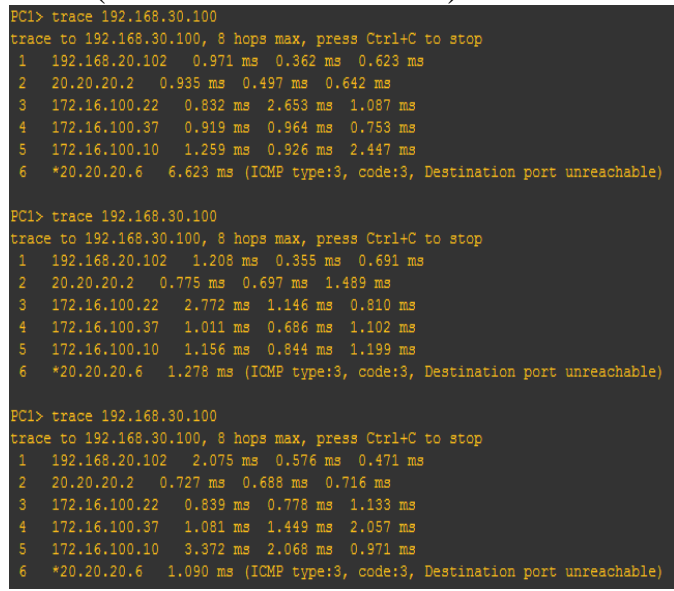

Gambar 2.31 Traceroute ketika link 1 down

Pada Gambar 2.31 terlihat paket hanya diteruskan melalui link WAN 2. Hal ini menunjukkan proses failover protocol GLBP dengan metode weight ini dapat berjalan dengan baik.

Selanjutnya link WAN 1 akan kembali diaktifkan, yang secara teori traceroute dari SITEA ke SITEB akan berlaku round robin karena nilai weight GLBP routerla dan router1b sama besar (200)

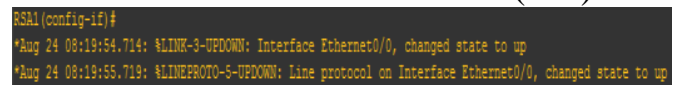

Gambar 2.32 Status Interface WAN link1 UP

Gambar 2.32 menunjukkan sesaat ketika link 1 kembli UP, maka fungsi GLBP untuk kedua link berjalan seperti semula, dimana load balancing dapat berjalan dengan baik membagi beban sama rata pada kedua link. 


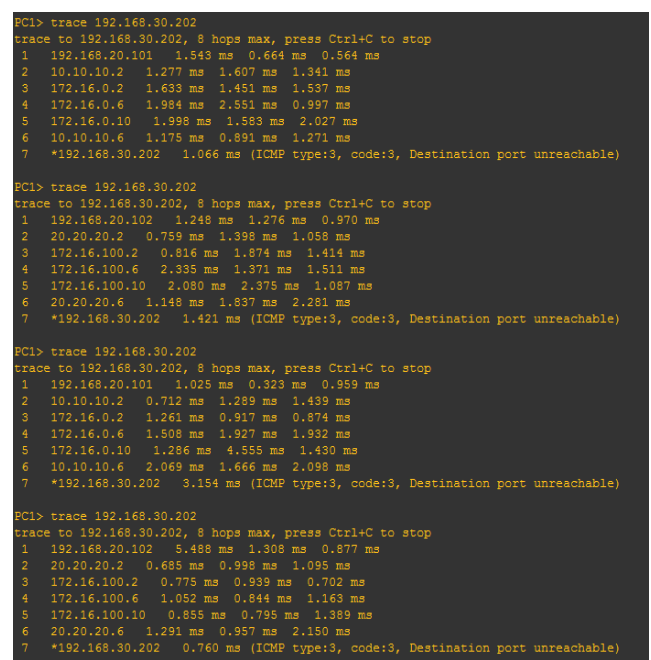

Gambar 2.33 Traceroute ketika link WAN 1 kembali UP

Test Failover GLBP Metode Weight Dengan STG Dan Traffic Generator

Kondisi ketika kedua link normal dan diberi beban traffic dengan sebesar 2 × 2 Mbps dari source SITE A destination SITE B :

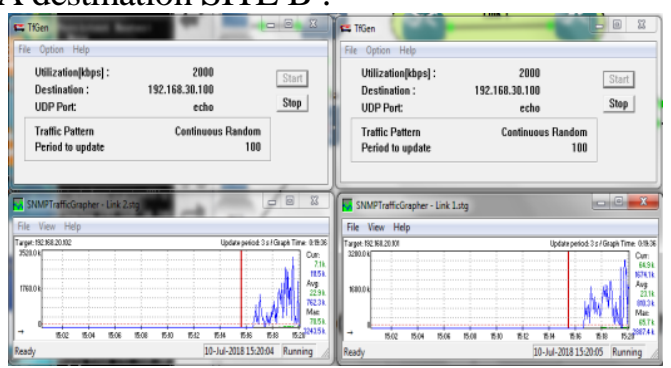

Gambar 2.34 Capture STG dan TFGen saat link WAN1 dan link WAN2 Normal

Sedangkan capture dibawah menunjukkan pola traffic pada saat link WAN 1 Down dan traffic berpindah seluruhnya ke link WAN 2 :

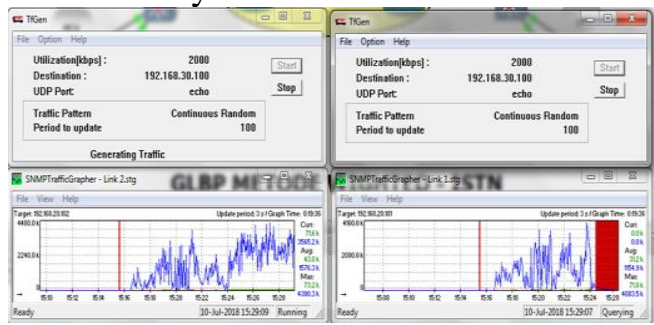

Gambar 2.34 Capture STG dan TFGen saat link WAN 1 down

Terlihat dari Gambar 2.34 bahwa link1 menunjukkan alarm (merah) dimana traffic tidak mengalir, dan traffic seluruhnya berpindah ke link WAN 2. Langkah selanjutnya yaitu memastikan traffic kembali seperti semula dengan mengaktifkan kembali link WAN 1.

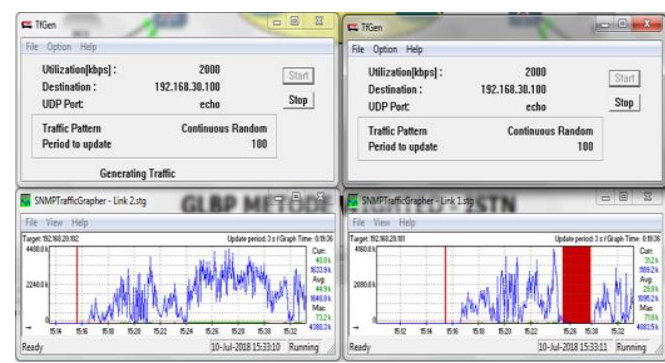

Gambar 2.35 Capture STG dan TFGen saat link1 aktif kembali

Pada Gambar 2.35 menunjukkan dengan alarm pada link 1 hilang dan traffic mulai mengalir di kedua link sesuai konsep Load Balancing.

\section{SIMPULAN} diambil:

Berikut beberapa kesimpulan yang dapat

1. Pada GLBP metode weight, pembagian beban data router ditentukan oleh nilai weight yang diberikan pada masing-masing router.

2. Perbandingan Nilai Weight yang diberikan pada Router akan menentukan jumlah paket data yang diteruskan pada router tersebut. Pada Simulasi terlihat ketika router RSA1 diberikan nilai weight 200 dan router RSA2 diberikan nilai weight 100 maka jumlah packet data yang diteruskan pada router RSA1 lebih banyak dua kali lipat dari router RSA2

3. Selain sebagai Load Balancing / pembagi beban traffic, GLBP metode weight juga berfungsi sebagai failover yang menjamin ketersediaan jaringan ketika salah satu perangkat router/link mengalami kerusakan.

4. Fungsi failover pada GLBP Metode weight tidak terpengaruh berapapun nilai weight yang diberikan pada masing-masing router.

\section{DAFTAR PUSTAKA}

Ahmad Zulhikam,

TCP/IP,

http://jaringankomputer.org/tcp-ip-fungsicara-

kerja-tcp-ip-dan-layer-tc-ip, diakses tanggal 3 April 2018

Oscar Rachman. 2008. Tcp/Ip Dalam Dunia Informatika Dan Telekomunikasi, Penerbit: Informatika, Jakarta

J. Saputro, Praktikum CCNA di Komputer Sendiri Menggunakan GNS3, Jakarta: Mediakita, 2010.

Iwan Sopana. Cisco CCNA-CCNP Routing dan Switching. Penerbit: Informatika, Jakarta. 
Sofana. 2014. Cisco CCNA dan Jaringan Komputer. Bandung. Informatika

http://www.cisco.com/en/US/docs/ios/12_2t/12_2t15/f eature/guide/ft_glbp. html, diakses tanggal 4 Juni 2018

Cisco System Inc. 2001. How Does Load Balancing Work?http://www.cisco.com/c/en/us/support/do cs/ip/border-gateway-protocol-bgp/5212-46.pdf, diakses tanggal 4 Juni 2018

http://www.cisco.com/c/en/us/td/docs/iosxml/ios/ipapp _fhrp/configuration/xe-3s/fhp-xe-3s-book/fhpglbp.html

Cisco System Inc. 2001. How Does Load Balancing Work?.http://www.cisco.com/c/en/us/support/do cs/ip/border-gateway-protocol-bgp/5212-46.pdf, diakses tanggal 4 Juni 2018

Cisco System Inc. 2001. Per-Packet Load Balancing. E-Book Cisco, http: // www.cisco.com / c / en / us /support/docs/ip/border-gateway-protocolbgp/5212-46.pdf, diakses tanggal 4 Juni 2018 